International Journal of Instruction e-ISSN: 1308-1470 • www.e-iji.net

Article submission code 20210302154807

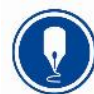

January $2022 \bullet$ Vol.15, No.1

p-ISSN: 1694-609X

pp. $237-258$

Received: $02 / 03 / 2021$

Revision: 18/06/2021
Accepted: 13/07/2021

OnlineFirst: $17 / 10 / 2021$

\title{
The Effectiveness of a SOIE Strategy Using Socio-scientific Issues on Students' Chemical Literacy
}

\section{Dewiyanti Fadly}

Universitas Negeri Malang, Indonesia, dewiyanti.fadly.1603319@students.um.ac.id

\section{Sri Rahayu}

Prof. Dr., Universitas Negeri Malang, Indonesia, sri.rahayu.fmipa@um.ac.id

\section{Wayan Dasna}

Universitas Negeri Malang, Indonesia, idasna@um.ac.id

\section{Yahmin}

Universitas Negeri Malang, Indonesia, yahmin.fmipa@um.ac.id

Scientific/chemical literacy is currently the goal of science education in many countries. Students' chemical literacy can be developed through an innovative learning strategy that explicitly direct student learning to aspects of chemical literacy. This research aimed to examine the effectiveness of SOIE (Strengthening, Orientation, Investigation, and Evaluation) innovative learning strategies on students' chemical literacy. The study used a quasi-experiment with pretest-posttest control group design. The research subjects consisted of two classes $(\mathrm{N}=68)$ first year students in a public university: the experimental $(\mathrm{n}=34)$ and the control $(\mathrm{n}=$ 34) groups. The experimental group was taught using the SSI context based SOIE strategy, while the control group was taught using conventional methods. Students' chemical literacy was measured using a chemical literacy test $(r=0.761)$ and the data were analysed using ANCOVA. The results showed that the innovative strategy significantly improves students' chemical literacy, and it greatly affected all aspects of chemical literacy measured (e.g. content, epistemic, and procedural knowledge). The average score of each aspect in the experimental group was higher than that of students in the control group. The research implication lies in incorporating explicit literacy aspects and socio-scientific issues in chemistry learning.

Keywords: chemical literacy, SOIE strategy, socio-scientific issues, science, teaching

\section{INTRODUCTION}

Science education in various developed and developing countries currently focus on developing scientific literacy (Fives et al., 2014; Barnea et al., 2010; AAAS, 2013; NGSS, 2013; NRC, 2012) and chemical literacy (Kohen et al., 2019; Sjöström \& Eilks, 
2018). Indonesia is also developing science education standards that focus on improving scientific literacy skills (Ni'mah, 2019; Ardiyanti, 2019). This effort begins because, in a survey conducted by the Program of International Student Assessment (PISA), Indonesian students aged 15-16 years-old are low in achievement. Indonesian students are in the top 10 from the bottom among PISA countries (Argina et al., 2017; Nida et al., 2020). Therefore, science educators in Indonesia are trying to find the best solution to improve students' scientific literacy skills. One of the methods suggested by science education research is through a learning process (Fakhriyah et al., 2017). The low scientific literacy results from the PISA survey can be used to predict that chemical literacy at higher education levels is also low. The development of chemical literacy will contribute to the development of scientific literacy in general (Shwartz et al., 2006). This study aims to develop students' chemical literacy by improving the quality of the learning process, especially through a learning strategy.

Chemical literacy emphasizes the skills of students to understand and explain phenomena with explicit language, read, write, evaluate information, communicate ideas, and use chemical concepts in making decisions (Cigdemoglu et al., 2017). To be a chemical literate person, he/she must think critically to make the right decisions and explain science-related problems through contexts or phenomena in everyday life (Bybee, 1997; Sandoval et al., 2016; Sjøberg, 2018). Therefore, chemical literacy can lead to the skill to understand science phenomenon. Chemical concepts will be the basis for understanding how the universe works and how humans should respond to existing natural events (Çiğdemoğlu et al., 2017; Hofstein et al., 2011; Jho et al., 2014; Overman et al., 2014; Rahayu, 2017; Ratcliffe, 2003; Sjöström \& Eilks, 2018; Traianou, 2006). People who have chemical literacy skills will understand what causes global warming, for example, how the process is from a chemical perspective, and what steps to be taken to reduce the impact of global warming from an individual, social, economic, political, and ethical perspectives.

Several approaches or strategies to improve scientific literacy have been applied and researched. The examples are the Science-Technology-Society (STS) and ScienceTechnology-Society-Environment (STSE) approaches. Yalvac et al. (2007) recommended that science teachers teach science knowledge through a scientific context so that students can find the relationship and meaning of science concepts with their daily lives. Chanapimuk et al. (2018) examined the STSE approach in science learning by raising chemical coating on corn plants, the use of many insecticides on plants, and growth hormones in banana plants. The study showed an increase in students' scientific literacy skills and suggested the importance of maximizing team or group cooperation in helping them practice scientific literacy skills. However, in its implementation, some researchers have found that STS and STSE have not touched the epistemic aspect as an indicator of scientific literacy (Chowdhurry, 2016; Zeidler et al., 2005). Both approaches have not involved students in context and argument and have not developed the skills to make decisions based on scientific evidence (Roberts \& Bybee, 2014; Zeidler, 2003). Still, in line with the ideas of the STS and STSE approaches, suggestions emerged to teach science through socio-scientific issues (SSI), which have more 
humanistic, relevant, real, and controversial characteristics in public (Aikenhead, 2005; Calabrase, 2003; Tal \& Kadmi, 2006).

Students' chemical literacy can be improved through approaches that involve socioscientific issues (SSI) or contexts that are relevant to students' daily lives, local or global community life (Stukey et al., 2013; Childs et al., 2015). SSI is based on issues or controversial issues in the universe that requires students to consider complex facts and integrate several related opinions and arguments to find solutions and alternatives in the future (Rahayu, 2017, 2018; Sadler, 2004; Sadler \& Zeidler, 2005; Sadler \& Donelly, 2006; Zeidler \& Sadler, 2009). It is believed that science learning in the SSI context supports the students' achievement of scientific literacy skills, such as content knowledge (Yörük, 2010), argumentation (Tyson, Treagust, \& Bucat, 1999), scientific explanations (Kinslow et al., 2019), and decision-making (Zeidler \& Sadler, 2009). Several studies have been conducted on using the SSI context and the results have been varied. For example, many students do not have sufficient knowledge to relate problems in SSI with the scientific concepts that underlie them (Bybee, 1997; Osborne \& Collins, 2001). A study by Herman (2015) showed that scientific literacy skills, such as the skills to argue, think critically, ethics and morals, appeared in students as learning experiences. Students started to show their awareness of the global warming impact and paid more attention to the environment. It seems that the use of the SSI context needs to be accompanied by an appropriate and effective learning strategy to improve chemical literacy.

Scientific literacy based on the PISA framework, requires three competencies, such as the ability to explain scientific phenomena, carry out scientific evaluation and investigation, and interpret scientific data and evidence (NRC, 2012; OECD, 2017). The types of knowledge needed to achieve the competencies are content, procedural, and epistemic knowledge. Content knowledge is the understanding of scientific or chemical concepts that have something to do with the studied natural phenomena. Procedural knowledge is practical knowledge that helps students understand science empirically through measurement, variable control, experimental procedures, and communicating data. Meanwhile, epistemic knowledge includes an understanding of the focus of the problem, observation, theory, hypothesis, strategy, and arguments that play a role in science, recognition of various forms of scientific inquiry, and the role that expert commentary plays in building credible knowledge.

This research focuses on achieving chemical literacy related to the concepts of chemical equilibrium and chemical kinetics. Both topics are essential in chemistry curriculum (Justi, 2002), although it is quite complicated to students (Julião, 2018; Pintrich, 2002; Tsai \& Jack, 2019). Students' difficulties in understanding both topics are caused by the lack of integration the concepts with students' real life (Bulte et al., 2006; O'Toole et al., 2020). In fact, chemistry is closely related to everyday life, and the concepts that contain many social scientific problems are reaction rate (Nurlatifah et al., 2018; Pluta et al., 2011) and chemical equilibrium (Eilks, 2002). Therefore, problems in SSI related to chemical equilibrium and kinetics can be developed in this study. 
Studies carried out on the 2006 and 2015 PISA data based on science in several Asian and European countries showed that science with guided inquiry could improve students' scientific literacy skills (Aditomo \& Klieme, 2020; Lau \& Lam, 2017; Kobarg et al., 2011; Cairns \& Areepattamannil, 2017; Forbes et al., 2020). The data also shows that low scientific literacy skills are associated with low student experience in inquiry. On the other hand, research on the effect of inquiry learning with SSI context on several aspects has been carried out. For example, Mahanani et al. (2019) examined the impact of inquiry learning with SSI context on high school students, and the results showed that students' critical thinking skills and explanatory skills improved. Similar studies show that inquiry-based SSI contexts can improve sociological reasoning, decision making, scientific literacy, and ethical thinking (Sadler, Barab, \& Scott, 2007; Walker \& Zeidler, 2007; Saunders \& Rennie, 2011). However, studies examining the effects of inquiry learning strategies with SSI context for training chemical literacy skills at the university level are still limited.

Studies related to the implementation of a learning strategy to improve chemical literacy have been done such as by Herscovitz, Kaberman, \& Dori (2012); Çiğdemoğlu, Arslan, \& Cam (2017); Rahayu (2018); Kohen, Herscovitz, \& Dori (2020). However, there was no other study which develop a learning strategy to improve chemical literacy skills at the university level, especially using the topic of kinetics and chemical equilibrium.

This study aims to examine the effectiveness of the SOIE strategy in improving students' chemical literacy by optimizing the SSI context and inquiry skills. The strategy is constructivist and inquiry-based and applies SSI characteristics (i.e. humanistic, relevant, real, and controversial) and the competencies needed to train students' chemical literacy skills. Inquiry-based learning involves students in finding main problems, collecting and analysing data, and arguing regarding the results of investigations. Inquiry-based learning can not only improve concept understanding but can also train students' procedural and epistemic skills, which are components of content knowledge of scientific literacy (Aditomo \& Klieme, 2020; Areepattamannil, 2012; Overton \& Mcgarvey, 2017; Sandoval et al., 2000; Shwartz et al., 2006). Through the implementation of SOIE learning strategies with SSI context, inquiry, and constructivism, theoretically, students can develop chemical literacy skills, including the skill to understand chemical concepts, procedural knowledge, and epistemic knowledge.

The SOIE strategy consisted of four stages of learning: strengthening, orientation, investigation, and evaluation. Strengthening becomes the first phase before new concepts are introduced to students through the SSI context. In this phase students are invited to recall their prior knowledge as a prerequisite to the learning new concepts. It is very important for students to relate prior concepts to the learning of new chemistry concepts and to understand the relationship between concepts (Donald, 2002) and the prior knowledge is the significant factor for students' success in learning chemistry (Boujaoude and Giuliano, 1991)

A chemically literate person has the competence in explaining scientific phenomena, evaluating and designing scientific investigations and interpreting scientific data and evidence. Starting from this view, in the SOIE strategy, there is an Orientation on SSI 
phase. Several controversial scientific phenomena were raised in a SSI context. Students are encouraged to understand SSI context through discussion of social issues related to science and the application of science and technology in large or potential industries (Solomon \& Aikenhead, 1994; Saunders \& Rennie, 2013; Tsai \& Jack, 2019).

The follow-up phase of the Orientation phase is the Investigation phase. In this phase students are trained to be able to solve problems through scientific methods, namely formulating problems, determining hypotheses, collecting data, analyzing data, and drawing conclusions (Miller, 2002; Atkins, 2015). Through group discussions, students will be trained in conveying ideas and opinions that are supported by facts and scientific evidence. As it is well known that problem solving skills and conveying ideas / opinions are competencies that must be achieved by students to be able to become a chemically literate person. The evaluation phase is the final phase of the SOIE strategy. In this phase, an evaluation of the learning process is carried out, in the form of feedback regarding the understanding the reaction rate and chemical equilibrium topics.

The formulation of the research problem is:

1. Does the implementation of the SOIE strategy in the context of socio-scientific issues affect students' chemical literacy skills?

2. How much influence does the SOIE learning strategy have on the knowledge aspects of chemical literacy (content, epistemic, and procedural)?

\section{METHOD}

\section{Research Design}

This study used a quasi-experiment with a pretest and posttest control group design (Creswell, 2012) to examine the effect of the SOIE learning strategy with SSI context on students' chemical literacy skills implemented in Chemical Equilibrium and Chemical Kinetics. Determination of the experimental class and control class using a simple random sampling technique. The experimental class was taught using SOIE learning strategies while the control class used expository learning. The time duration of each lesson was the same in all groups $(90 \mathrm{~min})$. The data collection instruments in this study use chemical literacy tests and learning achievement tests and are supported by structured observation and interviews. The data were analyzed descriptively and followed by statistics. In order to strengthen the explanation and validity of the data, we used confirmation triangulation and theory that underlies the findings.

\section{Subject and Data Collection}

The research subjects were first-year students (freshmen) of the chemical education study program $(\mathrm{N}=68)$ at a public university in Indonesia who took Basic Chemistry courses. Subjects came from two classes and were first tested with an initial ability test related to stoichiometry, solutions, and the concept of acids and bases. The test scores were analysed through the independent t-test with SPSS to see whether there was a difference in their initial abilities. This test obtained a p-value of 0.11 , which indicated that the two classes had no difference in initial ability. The two classes were then randomized to determine the experimental group $(\mathrm{N}=34)$ and the control group $(\mathrm{N}=$ 34). The study was conducted for six months, from January to early May 2019. The 
experimental group was taught by a lecturer using the SSI context-based SOIE strategy, and the control group was taught by a different lecturer using conventional methods (expository learning), which are lectures and algorithmic exercises.

\section{Teaching Program}

The strategy applied in this study consisted of four phases: strengthening prior knowledge, orientation on SSI, investigation, and evaluation (SOIE). The strengthening phase aims to link students' initial abilities with new concepts and the SSI context and strengthen their initial skills. According to Piaget (1954), knowledge is not static but continues to develop and change because students face new experiences that force them to build and modify previous knowledge. The orientation phase aims to adapt socioscientific issues (SSI) to students through discussion activities (Bossér, 2015; Hancock, 2019). The investigation phase aims to invite students to conduct inquiry activities by investigating the chemistry topic being studied related to the SSI context and practicing arguments online or offline. The evaluation phase aims to assess or provide feedback on how students understand the concepts being taught.

The steps for implementing the SOIE strategy in the context of socio-scientific issues (SSI) can be seen in detail in Table 1 below.

Table 1

The syntax of the SSI context-based SOIE strategy

\begin{tabular}{|c|c|c|}
\hline Phase & Activities & Description \\
\hline $\begin{array}{l}\text { Strengthening } \\
\text { Prior } \\
\text { Knowledge }\end{array}$ & $\begin{array}{l}\text { Identification and } \\
\text { strengthening of } \\
\text { prerequisite } \\
\text { concepts }\end{array}$ & $\begin{array}{l}\text { Students are shown learning videos related to the SSI context, questions, } \\
\text { and answers related to the prerequisite concepts in the video. }\end{array}$ \\
\hline \multirow[t]{2}{*}{$\begin{array}{l}\text { Orientation } \\
\text { on SSI }\end{array}$} & Problem analysis & $\begin{array}{l}\text { Students listen to lecturers' brief explanations regarding new concepts, } \\
\text { read and examine SSI context problems in teaching materials and } \\
\text { worksheets, identify variables in the SSI context, discuss the variables } \\
\text { found and formulate problems and hypotheses. }\end{array}$ \\
\hline & $\begin{array}{l}\text { Planning } \\
\text { investigation }\end{array}$ & $\begin{array}{l}\text { Students discuss in groups to determine what data is needed to solve } \\
\text { problems in the SSI context and develop investigative procedures to be } \\
\text { carried out. }\end{array}$ \\
\hline \multirow[t]{3}{*}{ Investigation } & $\begin{array}{l}\text { Collecting Data } \\
\text { (offline) }\end{array}$ & $\begin{array}{l}\text { Each group of students uses references related to the context they have } \\
\text { obtained previously (a week before the lecture, students are asked to } \\
\text { look for references about the given context). Next, students discuss } \\
\text { classifying scientific information from various sources and other } \\
\text { references. Students interpret the data on the references with the } \\
\text { guidance of the lecturer. }\end{array}$ \\
\hline & $\begin{array}{l}\text { Elaboration } \\
\text { with SSI } \\
\text { context (online) }\end{array}$ & $\begin{array}{l}\text { Students look back at the SSI context that has been discussed in class } \\
\text { (offline). In synchronous online meetings, students discuss with the } \\
\text { lecturer on the discussion forum about the progress of the investigation } \\
\text { and the obstacles that may be faced, put forward arguments, clarify } \\
\text { results, and conclude the results of the investigation. }\end{array}$ \\
\hline & $\begin{array}{l}\text { Communication } \\
\text { (offline) }\end{array}$ & $\begin{array}{l}\text { Each group presents the results of their investigation and discussion in } \\
\text { front of the class. Students listen to feedback (reflections) from other } \\
\text { groups and lecturers. }\end{array}$ \\
\hline Evaluation & & $\begin{array}{l}\text { The lecturer evaluates how learning success has been carried out, and } \\
\text { the students conclude essential things from what has been discussed. }\end{array}$ \\
\hline
\end{tabular}


The SSI context used in learning with the SOIE strategy was global warming and other scientific phenomena related to global warmings, such as (1) NOx pollutant gases in the atmosphere. This context discusses the exhaust gases of NOx motorized vehicles and their chemical reactions in the atmosphere, which can exacerbate global warming; (2) The greenhouse effect in Indonesia. This context discusses the causes of the greenhouse effect caused by $\mathrm{CO}_{2}, \mathrm{~N}_{2} \mathrm{O}, \mathrm{CH}_{4}$, and $\mathrm{CFC}$ gases, and the sources of greenhouse gases and their impacts; (3) Ocean acidification. This context discusses one of the effects caused by global warming, namely the decrease in the $\mathrm{pH}$ of seawater which damages marine ecosystems.

\section{Research Instruments}

The research instrument is a chemical literacy test developed using the PISA framework. There are three competencies measured in the test: (1) explaining social scientific phenomena; (2) interpretation of data and scientific evidence; and (3) evaluation and design of scientific investigations. The test also measures three types of knowledge needed to achieve chemical literacy competencies: content knowledge, procedural knowledge, and epistemic knowledge (PISA, 2015; OECD, 2015; Shwartz et al., 2006). The chemical literacy test consists of 30 essay questions with short answers. Two professors and four lecturers in chemistry education tested the content and construct validity of the test using validation instruments and obtained an instrument validity of $96 \%$. These results indicate that the instrument is valid for use in research. The test was tested on 84 students who took Basic Chemistry II courses, and the Cronbach Alpha reliability was obtained, as shown in Table 2.

Table 2

Cronbach alpha value for chemical literacy skills test items

\begin{tabular}{ll}
\hline Item & Cronbach Alpha Value $(\mathrm{r})$ \\
\hline Content & 0.712 \\
\hline Epistemic & 0.680 \\
\hline Procedural & 0.755 \\
\hline Overall & 0.761 \\
\hline
\end{tabular}

The reliability of the test and every aspect of scientific literacy measured indicate that the test is reliable. According to Majid (2004), a useful questionnaire reliability index results in a value higher than 0.60 . Examples of chemical literacy problems can be found in the Appendix.

\section{Data Analysis}

The data were analysed descriptively to see the percentage of chemical literacy skills with a significance of $\mathrm{p}=0.05$. The prerequisite test used the Kolmogorov-Smirnov Test for the normality test and the Levene test for the homogeneity test. To test the first research question, to find out whether there was a significant difference in chemical literacy abilities between the experimental group and the control group, the statistical analysis used was the ANCOVA test. All analysis results obtained were significant if a significance value of $\mathrm{p}<0.05$ was obtained. ANCOVA statistical analysis of students' answer scores used the SPSS 22.0 program. 
The second research question was examined by implementing the Cohen's d effect size to find out how much the SOIE learning strategy's effectiveness in improving every aspect of knowledge in chemical literacy (content knowledge, procedural knowledge, and epistemic knowledge).

Also, to testing the validity and reliability of the item questions from the developed chemical literacy test, the test went through the interrater reliability estimation process to assess the agreement between the raters in assessing each students' responses. In this study, two people were involved in the interrater process. The agreement between raters is analysed using the kappa coefficient with a rating scale of 0 to 1 , where a score of 1 indicates perfect agreement and a score of 0 indicates no agreement. The reliability test results showed that the kappa coefficient value obtained was 0.89 , which indicates that both raters had the same assessment.

\section{FINDINGS}

RQ1. Does the implementation of the SOIE strategy in the context of socioscientific issues affect students' chemical literacy skills?

The data obtained from this study were the test scores of students' chemical literacy skills from the experimental and the control groups. Table 3 below presents a descriptive recapitulation of the research results.

Table 3

Descriptive analysis results of students' chemical literacy test results

\begin{tabular}{llllll}
\hline Group & Scores & Maximum & Minimum & Mean & Standard Deviation \\
\hline \multirow{2}{*}{ Experimental } & Pretest & 55 & 25 & 39.07 & 9.31 \\
\cline { 2 - 6 } & Posttest & 79 & 31 & 57.26 & 10.20 \\
\hline \multirow{2}{*}{ Control } & Pretest & 57 & 20 & 32.46 & 8.67 \\
\cline { 2 - 6 } & Posttest & 63 & 27 & 48.54 & 9.51 \\
\hline
\end{tabular}

Based on Table 3, the average mean scores of pretest and posttest in the experimental group are higher than the control group. These results indicate that the SOIE learning strategy in the experimental group gives better results than the control group.

To test the hypothesis, the data from the chemical literacy test were analysed using the ANCOVA test. Before carrying out this test, a prerequisite test was carried out through the normality test with the Kolmogorov-Smirnov test and the Levene test for homogeneity test.

Based on the normality test results, the pretest and posttest data for both groups obtained a significance value of $\geq 0.05$, which indicates that all data were normally distributed. The data homogeneity test used the Levene test and the significance value (Sig.) based on the mean was $0.400 \geq 0.05$, so it can be concluded that the variance of the experimental group and control group data was homogeneous. Because the learning outcome data for the experimental group and the control group have met the normal and homogeneous criteria, the analysis can be continued with the ANCOVA test. 
The SOIE learning strategy with SSI context's effectiveness can be seen by comparing the chemical literacy skills of the experimental group and the control group. Table 4 shows the ANCOVA test results to determine whether there is an effect of implementing the SOIE learning strategy with SSI context on students' chemical literacy skills.

Tabel 4

ANCOVA test analysis results on students' chemical literacy skills

\begin{tabular}{llllll}
\hline Group & $\mathrm{N}$ & Mean & SD & F & Sig (p) \\
\hline Experimental & 34 & 57.26 & 10.20 & 4.421 & 0.039 \\
Control & 34 & 48.54 & 9.51 & & \\
\hline
\end{tabular}

From the SPSS output in Table 4, the sig. value is obtained for the chemical literacy pretest covariate of $0.000<0.05$. This data indicates that at the $95 \%$ confidence level, it can be said that there is an effect of the initial ability (pretest) on students' chemical literacy skills. From the same SPSS output, the sig. for changes in learning strategies is $0.039<0.05$. It indicates that there is an effect of implementing the SOIE learning strategy with SSI context on students' chemical literacy.

RQ 2. How much influence does the SOIE learning strategy have on the knowledge aspects of chemical literacy (content, epistemic, and procedural)?

The results of the analysis per chemical literacy aspect are presented in Table 5.

Table 5

Descriptive analysis results of students' chemical literacy test results for three chemical literacy aspects

\begin{tabular}{lllllll}
\hline \multirow{2}{*}{ Scores } & $\begin{array}{l}\text { Chemical } \\
\text { Aspects }\end{array}$ & Literacy & Maximum & Minimum & Mean & Standard Deviation \\
\hline \multirow{2}{*}{ Pretest } & Content & 70 & 27 & 47.91 & 11.93 \\
\cline { 2 - 6 } & Epistemic & 64 & 9 & 25.15 & 14.03 \\
\cline { 2 - 6 } & Procedural & 67 & 0 & 20.91 & 17.28 \\
\hline \multirow{2}{*}{ Posttest } & Content & 83 & 40 & 66.18 & 10.87 \\
\cline { 2 - 6 } & Epistemic & 73 & 21 & 45.35 & 14.06 \\
\cline { 2 - 6 } & Procedural & 85 & 30 & 56.56 & 12.46 \\
\hline
\end{tabular}

Based on Table 5, the average score for the content aspect is higher than the average for the epistemic and procedural aspects. The average value of epistemic aspects is the lowest among the three aspects. From the comparison of pretest scores for the three aspects, procedural aspects are the lowest among the three aspects of chemical literacy. The standard deviation of posttest scores for epistemic aspects is the highest among the three aspects of chemical literacy.

Students' chemical literacy skills are viewed from three aspects: knowledge related to chemical concepts (content), procedural knowledge, and epistemic knowledge. The ANCOVA test was carried out to see a more specific effect on the three aspects of knowledge. The results are presented in Table 6. 
Tabel 6

ANCOVA test analysis results of students' chemical literacy aspects

\begin{tabular}{llllll}
\hline Knowledge Aspect & $\mathrm{N}$ & Mean & SD & F & Sig (p) \\
\hline Content & 34 & 29.37 & 16.10 & 4.510 & 0.037 \\
Epistemic & 34 & 16.14 & 21.99 & 17.308 & 0.000 \\
Prosedural & 34 & 38.17 & 9.32 & 9.546 & 0.003 \\
\hline
\end{tabular}

Further analysis was carried out to determine how effective the SOIE learning strategy in improving every aspect of knowledge on students' chemical literacy using Cohen's d effect size test. The results of the analysis are presented in Table 7.

Table 7

Effect size Cohen's D test results from chemical literacy aspects

\begin{tabular}{lll}
\hline Knowledge Aspect & Effect Size & Description \\
\hline Content Aspect & 1.601 & Large \\
\hline Epistemic Aspect & 1.438 & Large \\
\hline Procedural Aspect & 2.367 & Large \\
\hline
\end{tabular}

Based on the results of Cohen's d effect size test in Table 8, the three aspects of knowledge have a significant influence. However, from the results obtained, the procedural aspect has the largest effect size compared to the content and epistemic aspects, while the epistemic aspect has the lowest effect size.

\section{DISCUSSION}

The ANCOVA test results are presented in Table 5, showing that the SOIE learning strategy with SSI context can significantly improve chemical literacy skills in the experimental group $(\mathrm{F}=0.039, \mathrm{p}<0.05)$, which indicates that there is an influence from the SOIE strategy. These results are supported by the data in Tables 3 and Table 6 , where the mean score of the experimental group is higher than the control group, and there is an increase in the average score of students' chemical literacy skills after the implementation of the SOIE learning strategy. Several factors cause this, one of which is that the SOIE strategy can hone students' thinking skills. One of the competencies that must be achieved to be able to literate in chemistry is to explain the SSI phenomenon. The SOIE learning strategy trains some of the thinking skills needed in chemical literacy using several methods: the discussion method, the scientific inquiry method, and the group work method. The group discussion method is one of the stages in the SOIE learning strategy with SSI context. The SSI context related to global warming is discussed in groups under the guidance of a lecturer.

The result show that implementation of SOIE strategy is more effective in improving student chemical literacy compared with the conventional learning (expository learning). The experimental group taught using the SOIE strategy got a better result because the learning process focuses on honing the various thinking skills needed in chemical literacy. Critical thinking and inquiry skills, which are thinking skills trained in the SOIE strategy, can improve students' ability to analyze and understand scientific phenomena from the given SSI context. This result is in line with Sutiani, Situmorang \& Silalahi 
study that inquiry learning can increase student activity, motivation, interest and critical thinking skills (Sutiani, Situmorang, \& Silalahi, 2021). In addition, the problem-solving skills that were trained in the experimental class made them accustomed to analyzing and finding solutions to scientific problems that existed in the SSI context. These results are in line with studies conducted by Çiğdemoğlu \& Geban where contexts that are relevant to student life can improve chemical literacy skills (Çiğdemoğlu \& Geban, 2015)

Previous research, which also used the discussion method through the SSI context, was significantly able to arouse curiosity and a sense of awe and wonder in students that many can be explored more in-depth on the same science topic (Zeidler, 2014; Kahn \& Zeidler, 2019). Several previous studies that used SSI context found students actively integrate their knowledge to strengthen information acceptance, deepen understanding, and can make decisions that consider many aspects, including morals and ethics (Eilks, 2002; Jho \& Yoon, 2014; Tsai \& Jack, 2019; Lee et al., 2012). In this study, through group discussions, students were able to explain scientific phenomena such as global warming and evaluate explanations related to scientific phenomena from various perspectives. This study also suggests the importance of maximizing team or group collaboration to help them practice chemical literacy skills.

The SOIE learning strategy with SSI context trains problem solving and inquiry skills by adopting the scientific inquiry method in the steps of the SOIE strategy, such as the ability to identify problems, to make problem formulations, to conclude process steps in scientific inquiry. However, students sometimes have difficulty in solving problems. This might because of their limited knowledge of science and often fail to consider and link to broader social and global aspects (Hofstein et al., 2011; Herman, 2015; Khishfe, 2012; Liu et al., 2011). Simultaneously, problem-solving skills are among the basic skills needed in scientific literacy, which are also elements of scientific inquiry and scientific knowledge (Khalick et al., 2004; Vieira, 2014). In this study, these thinking skills were trained in the Investigation phase, which was carried out offline and online to overcome the lack of time in training scientific literacy skills. The habit of reading various references and writing down the results of the reading process is a way for students to analyze, interpret data, and draw conclusions (Cigdemoglu \& Geban, 2015). The chemical literacy skills through the use of SSI context with the theme of NOx gas pollution, the greenhouse effect, and ocean acidification requires students to explore the focus of the problem, to find answers by integrating chemical concepts, reliable scientific data, and experimental results that can support the results of student's investigations.

Chemical literacy in this study measures competence in three aspects: content, epistemic, and procedural aspects. Of the three aspects of chemical literacy that have a large effect size, the SOIE learning strategy with SSI context shows very effective for the three aspects of chemical literacy. In the content aspect, the effect size obtained is 1.061, which indicates that the SOIE strategy has a large effect on the content aspect. The reason is that when implementing the SOIE strategy, the lecturer used the SSI context that is genuinely relevant and related not only to student life but also closely 
related to the chemical concepts to be taught. The SSI context has a connection that is relevant to the science concepts, students' daily life, and global phenomena that occur in society so that students can more easily understand science content through the SSI context (Dauer \& Long, 2015; Klosterman \& Sadler, 2010; Peel et al., 2019; Kolst $\varnothing$, 2006; Sadler, 2004; Zeidler, 2003). Besides, SOIE learning steps in the "Orientation" phase and the "Investigation" phase help students hone their skills to argue and think critically in solving problems related to the SSI context. So students not only gain depth of knowledge related to the SSI context raised but also deepen knowledge of chemical concepts. The depth of science content or useful concepts from students can improve scientific literacy skills (NRC, 1996; Ogunkola, 2013).

The epistemic knowledge aspect, which refers to acquiring scientific knowledge through evaluation and validation of experimental designs related to procedures and findings (OECD, 2016; PISA, 2015), is trained in the "Investigation" phase of the SOIE learning strategy. From the epistemic aspect effect size test, it was obtained 1.438, which also indicates that the SOIE strategy has a significant effect on the epistemic aspect. In the SOIE strategy phases, students are trained to understand how to acquire scientific knowledge through scientific methods such as formulating problems, making hypotheses, analysing data, and making decisions. Students are also invited to assess the scientific approach's validity and the tentative nature of scientific knowledge. The SSI context used in this study leads to a deep epistemic understanding (Eastwood et al., 2012). The increase in epistemic knowledge is based on the depth of previous knowledge, good knowledge structures, conceptual understanding, and the ability to link concepts (Pintrich, 2002; Hiebert \& Carpenter, 1992; Hiebert \& Lefevre, 1986). The epistemic knowledge that is trained through SOIE learning strategies invites students to reflect on what they already know, how they know it, why they believe it. Students' epistemic knowledge from the SSI context teaches them that scientific knowledge is also related and developed through social issues (Sandoval et al., 2000), such as global warming, as in this study. Through a discussion process that provokes students to argue, they can evaluate scientific information to build theories that can explain natural phenomena, leading to the development of epistemic knowledge (Sandoval et al., 2000; Kelly \& Licona, 2018).

Implementing the SOIE strategy has a significant effect on aspects of procedural knowledge, as evidenced by the effect size value of 2.367 . Understanding related to procedural knowledge is the process of how science is understood through observation, building relationships between plans, hypotheses, and estimates, collecting and interpreting data (PISA, 2015; Harlen, 2000; Harlen \& Holroyd, 1995; Traianou, 2006). Epistemic and procedural knowledge is always in line with the process of building scientific knowledge. The data analysis results show that procedural knowledge has a more significant effect than content knowledge. It indicates that students' procedural knowledge does not represent their content knowledge. It is easier for students to understand chemical concepts through systematic procedural knowledge. This result is in line with the findings of Yilmaz and Yalçin (2012), where students find it challenging to connect and change understanding related to procedural knowledge into understanding content knowledge. The process of acquiring procedural knowledge is 
trained in the learning phases of the SSI context SOIE strategy, where students do laboratory activity to understand chemical concepts by observing, collecting data, analysing, and making decisions. Students then corroborated the laboratory activity results obtained by seeking support for related scientific research data.

Based on the description of the implementation of the learning phases in SOIE strategy with SSI context, it is illustrated that each phase can train chemical literacy skills through the development of skills in three aspects of knowledge (content, epistemic, and procedural). Through the phases of "strengthening, orientation, investigation and evaluation" on the SOIE strategy, trained students can argue, link related chemical concepts, carry out stages of the scientific method in solving problems to problemsolving. When students get used to doing these stages, chemical literacy skills can be honed well.

\section{CONCLUSIONS AND SUGGESTIONS}

SOIE learning strategy with SSI context significantly affects student chemical literacy skills related to the topics of chemical equilibrium and chemical kinetics. The chemical literacy skills of students in the experimental group were better than the control group. SOIE learning strategy highly contributes to the three aspects of knowledge in chemical literacy (e.g. content, epistemic, and procedural knowledge).

The findings of this study imply the importance of an appropriate strategy for training chemical literacy skills. The SOIE strategy specifically sharpens the thinking skills needed to be able to literate in chemistry, such as: (1) critical and analytical thinking, (2) problem solving, (3) conveying ideas and opinions through cooperative learning.

The implementation of the SOIE strategy is supported by learning tools that are also designed to improve students' chemical literacy skills. For further research, other researchers can develop even better learning tools specifically designed to hone critical thinking skills and skills in problem solving that support increased chemical literacy skills.

The implementation of the SOIE learning strategy with SSI context requires a more careful preparation and learning design to maximize the implementation of each phase of the SOIE strategy, including the availability of supporting facilities, especially to optimize the online discussion. The strategy in current study, however, has not been implemented optimal due to insufficient supporting facilities for online activity and only used two topics, chemical kinetics and chemical equilibrium. For future research, the next researchers could test the effectiveness of this learning strategy on other chemical topics that can be more related to various SSI phenomena.

\section{REFERENCES}

Aditomo, A., \& Klieme, E. (2020) Forms of inquiry-based science instruction and their relations with learning outcomes: evidence from high and low-performing education systems. International Journal Science Education, 42, 504-525.

Aikenhead, G. (2005). Research into STS science education. Educación Química, 16(3), 384-397. 
American Association for the Advancement of Science (AAAS). (2013). Science for All Americans: Education for a changing future. Oxford University Press. Retrieved 03 September 2019 from http://www.aaas.org/report/science-all-americans.

Arbid, S. S., \& Tairab, H. H. (2020). Science teachers' views about inclusion of socioscientific issues in UAE science curriculum and teaching. International Journal of Instruction, 13(2), 733-748.

Ardiyanti, Y., Suyanto, S., \& Suryadarma, IGP. (2019). The role of student's science literacy in Indonesia. Journal Physics Conference Series, 1321, 1-6.

Areepattamannil, S. (2012). Effects of inquiry-based science instruction on science achievement and interest in science: Evidence from Qatar. Journal Education Research, $105,134-146$.

Argina, A.W., Mitra, D., Ijabah, N., \& Setiawan, R. (2017). Indonesian PISA Result: What Factors and What Should be Fixed. In Proceedings of the $1^{\text {st }}$ Education and Language International Conference, Semarang, Indonesia.

Atkins, P. (2015). Chemistry Education Best Practice, Opportunities, and Trends. Media Pte Ltd: Singapore.

Autieri, S.M., Amirshokoohi, A., \& Kazempour, M. (2016). The sciencetechnologysociety framework for achieving scientific literacy: an overview of the existing literature. European Journal of Science and Mathematics Education, 4(1), 7589.

Barnea, N., Dori, Y. J., \& Hofstein, A. (2010). Development and implementation of inquiry-based and computerized-based laboratories: Reforming high school chemistry in Israel. Chemical Education Research \& Practice, 11, 218-228.

Bennett, J., \& Holman, J. (2002). Context-based approaches to the teaching of chemistry: What are they and what are their effects? In J. Gilbert (ed), Chemical education research-based practice. Dordrecht, Netherlands: Kluwer Academic Publishers.

Bossér, U., Lundin, M., Lindahl, M., \& Linder, C. (2015). Challenges faced by teachers implementing socio-scientific issues as core elements in their classroom practices. European Journal of Science and Mathematics Education, 3, 159-176.

Bulte, A. M. W., Westbroek, H. B., De Jong, O., \& Pilot, A. (2006). A research approach to designing chemistry education using authentic practices as contexts. International Journal Science Education, 28, 1063-1086.

Bybee, R. W. (1997). Achieving scientific literacy: From purpose to practices, 1st ed. Portsmouth, New Hampshire, UK: Heinemann.

Bybee, R. W. (2012). Scientific literacy in environmental and health education. In Albert Zeyer \& Regula Kyburz-Graber (Eds). Science, environment, health: Towards a renewed pedagogy for science education. London: Springer Nature. 
Cahyana, U., Supatmi, S., Erdawati., \& Rahmawati, Y. (2019). The influence of webbased learning and learning independence toward student's scientific literacy in chemistry course. International Journal of Instrution, 12(4), 655-668.

Cairns, D., \& Areepattamannil, S. (2017). Exploring the relations of inquiry-based teaching to science achievement and dispositions in 54 countries. Research in Science Education, 1-23.

Calabrese, B. A. (2003). Teaching science for social justice. New York: Teacher's College Press.

Chanapimuk, K., Sawangmek, S., \& Nangngam, P. (2018). Using science, technology, society, and environment (STSE) approach to improve the scientific literacy of grade 11 students in plant growth and development. Journal Science Learning, 2, 14-20.

Childs, P. E., Hayes, S., \& O’Dwyer, A. (2015). Chemistry and everyday life: relating secondary school chemistry to the current and future lives of students. Rotterdam: Sense.

Chowdhury, M. A. (2016). Gifted education in science and chemistry: Perspectives and insights into teaching, pedagogies, assessments, and psychosocial skills development. Journal For the Education Gifted Young Scientists, 4, 53-66.

Çiğdemoğlu, C., \& Geban, Ö. (2015). Improving students " chemical literacy levels on thermochemical and thermodynamics concepts through a context-based approach. Chemical Education Research \& Practice, 16, 302-317.

Çiğdemoğlu, C., Arslan, H. O., \& Cam, A. (2017). Argumentation to foster pre-service science teachers' knowledge, competency, attitude, on the domains of chemical literacy of acids and bases. Chemical Education Research \& Practice, 18, 288-303.

Creswell, J.W. (2012). Educational research: planning, conducting, and evaluating quantitative and qualitative research. 4th ed. Boston: Pearson.

Eastwood, J.L., Sadler, T.D., Zeidler, D.L., \& Lewis, A. (2012). Contextualizing Nature of Science instruction in socioscientific issues. International Journal Science Education, 34, 1-27.

Eilks, I. (2002). Teaching biodiesel: A sociocritical and problem-oriented approach to chemistry teaching and students' first views on it. Chemical Education Research \& Practice, 3, 77-85.

Fakhriyah, F., Masfuah, S., Roysa, M., Rusilowati A., \& Rahayu E. S. (2017). Students' science literacy in the aspect of content science? Jurnal Pendidikan IPA Indonesia, 6, 81-87.

Fives, H., Huebner, W., Birnbaum, A.S., \& Nicolich, M. (2014). Developing a measure of scientific literacy for middle school students. Science Education, 98(4), 549-580.

Forbes, C. T., Neumann, K., \& Tiska, A.S. (2020). Patterns of inquiry-based science instruction and student science achievement in PISA 2015. International Journal of Science Education, 42(5), 1-24. 
Hancock. (2019). Selecting socio-scientific issues for teaching a grounded theory study of how science teachers collaborative design SSI-based curricula. Science Education, 28, 639-667.

Harlen, W. (2018). The teaching of science in primary school's 7th ed. London: David Fulton.

Harlen, W., \& Holroyd, C. (1995). Primary teachers' understanding of concepts in science: Impact on confidence and teaching. International Journal Science Education, 19, 93-105.

Herman, B. C. (2015). The influence of global warming science views and sociocultural factors on willingness to mitigate global warming. Science Education, 1, 1-38.

Herscovitz O., Kaberman Z., Saar L. \& Dori Y. J., (2012), The relationship between metacognition and the ability to pose questions in chemical education, in A. Zohar and Dori Y. J. (ed.), Metacognition in Science Education: Trends in Current Research, Dordrecht, The Netherlands: SpringerVerlag, pp. 165-195.

Hiebert, J., \& Lefevre, P. (1986). Conceptual and procedural knowledge in mathematics: An introductory analysis. In Conceptual and procedural knowledge: The case of mathematics, J. Hiebert ed. NJ: Erlbaum.

Hiebert, J., \& Carpenter, T. P. (1992). Learning and teaching with understanding. In Handbook of research on mathematics teaching and learning, D. A. Grouws (ed). London: Macmillan Publishing Co, Inc.

Hofstein, A., Eilks, I., \& Bybee, R. (2011). Societal issues and their importance for contemporary science education - a pedagogical justification and the state-of-the-art in Israel, Germany, and the USA. International Journal of Science and Mathematics Education, 9(6), 1459-1483.

Jho, H., Yoon, H. G., \& Kim, M. (2014). The relationship of science knowledge, attitude and decision making on socio-scientific issues. Science Education, 23, 11311151.

Julião, M. (2018). Teaching chemical equilibria: A contextualized scientific method and forensic chemistry class. Journal of Laboratory Chemical Education, 6, 148-155.

Justi, R. (2002). Teaching and learning chemical kinetics. In J. K. Gilbert, O. De Jong, R Justi, D. Treagust J. H. Van Driel (eds), Chemical education: Towards research-based practice. Netherlands: Dordrecht.

Kahn, S., Zeidler, D. L. (2019). A conceptual analysis of perspective taking: Positioning a tangled construct within science education and beyond. Science Education, 28, 605638.

Kelly, G.J., \& Licona, P. (2018). Epistemic practices and science education. In M.R. Matthews (ed), History, philosophy, and science teaching. New York: Springer International Publishing. 
Khalick, F., Boujaoude, S., Duschl, R., \& Lederman, NG., Mamlok-Naaman, R., Hofstein, A., Niaz, M., \& Treagust, D. (2004). Inquiry in science education: International perspectives. Science Education, 88, 397-419.

Khishfe, R. (2012). Nature of science and decision making. International Journal of Science Education, 34, 67-100.

Kinslow, A. T., Sadler, T. D., \& Nguyen, H. T. (2019). Socio-scientific reasoning and environmental literacy in a field-based ecology class. Environmental Education Research, 25, 388-410.

Klosterman, M. L., \& Sadler, T. D. (2010). Multi-level assessment of scientific content knowledge gains associated with socio-scientific issues-based instruction. International Journal of Science Education, 32, 1017-1043.

Kohen, Z., Herscovitz, O., \& Dori, Y. J. (2020). How to promote chemical literacy? Online question posing and communicating with scientist. Chemical Education Research \& Practice, 21, 250-266.

Kolstø, S.D. (2006). Patterns in students' argumentation confronted with a risk-focused socio-scientific issue. International Journal of Science Education, 28, 1689-1716.

Lau, K., \& Lam, T. Y. (2017). Instructional practices and science performance of 10 top-performing regions in PISA 2015. International Journal of Science Education, 122.

Lee, H., Chang, H., Choi, K., Kim, S-W., \& Zeidler, D. L. (2012). Developing character and values for global citizens: Analysis of pre-service science teachers' moral reasoning on socio-scientific issues. International Journal of Science Education, 34, 925-953.

Lin, Y-C., Liang, J-C., \& Tsai, C-C. (2010). The relations between scientific epistemological beliefs and approaches to learning science among science-major undergraduates in Taiwan. Journal of Science Education and Technology, 21, 796-807.

Liu, S. Y., Lin, C. S., \& Tsai, C. (2011). College students' scientific epistemological views and thinking patterns in socio-scientific decision making. Science Education, 95, 497-517.

Lumpe, A.T., Haney, J. J., \& Czerniak, C. M. (1998). Science teacher beliefs and intentions to implement Science-Technology-Society (STS) in the classroom. Journal of Science Teacher Education, 9, 1-24.

Lynch, M. D. (1997). The effect of cognitive style, method of instruction, and visual ability on learning chemical kinetics. PhD thesis. Iowa State University, Ames, Iowa, USA.

Mahanani, I., Rahayu, S., \& Fajaroh, F. (2019). The effect of inquiry-based learning with socioscientific issues context on critical thinking skills and scientific explanation. Jurnal Kependidikan Penelitian Inovasi Pembelajaran, 3/1, 53-68.

Miller, J.D. (2000). The development of civic scientific literacy in the United States. In D.D Kumar and D.E. Chubin (Eds). Science, technology, and society: A sourcebook on research and practice. Kluwer Academic/Plenum Press: New York. 
National Research Council (NRC). (1996). National science education standards. Washington, USA: National Academies Press.

National Research Council (NRC). (2012). A framework for K-12 science education: Practices, crosscutting concepts, and core ideas. Washington, USA: National Academies Press.

National Research Council (NRC). (2013). Education for life and work: developing transferable knowledge and skills in the $21^{\text {st }}$ century. Washington, USA: National Academies Press.

NGSS Lead States. (2013). Next Generation Science Standards: For states, by states. Washington, USA: National Academies Press.

Nida, S., Rahayu, S., \& Eilks, I. (2020). A survey of indonesian science teachers' experience and perceptions toward Socio-Scientific issues-based science education. Education Science, 10, 1-15.

Ni'mah, F. (2019). Research Trends of Scientific Literacy in Indonesia: Where Are We? Jurnal Inovasi Pendidikan IPA, 5, 23-30.

Nurlatifah, S., Tukiran., \& Erman. (2018). The development of learning material using learning cycle $7 e$ with socio-scientific issues context in rate of reaction to improve student's argumantation skills in senior high school. Mathematics, Informatics, Science, and Education International Conference: Advances in Intelligent Systems Research (AISR). Atlantis Press: Paris.

OECD. (2006). Assessing Scientific, Reading and Mathematical Literacy: A Framework for PISA. Paris, France: OECD Publishing.

OECD. (2017). PISA 2015 science framework. Paris, France: OECD Publishing.

Ogunkola, B. J. (2013). Scientific literacy: conceptual overview, importance, and strategies for improvement. Journal of Educational and Social Research, 3, 265-274.

Osborne, J. F., \& Collins, S. (2001). Pupils' views of the role and value of the science curriculum: a focus-group study. International Journal Science Education, 23, 441468.

O'Toole, J. M., McKoy, K., Freestones, M., \& Osborn, J-A. (2020). 'Scientific literacy': An exercise in model building. Education Sciences, 10, 204.

Overman, M., Vermunt, J. D., Meijer, P. C., Bulte, A. M. W., \& Brekelmans, M. (2014). Students' perceptions of teaching in context-based and traditional chemistry classrooms: comparing content, learning activities and interpersonal perspectives. International Journal Science Education, 36, 1871-1901.

Overton, T., \& Mcgarvey D. J. (2017). Development of key skills and attributes in chemistry. Chemical Education Research \& Practice, 18, 401-402.

Parlan, P., Ibnu, S., Rahayu, S., \& Suharti, S. (2018). Effects of the metacognitive learning strategy on the quality of prospective chemistry teacher'scientific explanations. International Journal of Instruction, 11(4), 673-688. 
Peel, A., Zangori, L., Friedrichsen, P., Hayes, E., \& Sadler, T. (2019). Students' modelbased explanations about natural selection and antibiotic resistance through socioscientific issues-based learning. International Journal Science Education, 41, 510-532.

Pintrich, P. R. (2002). Future challenges and direction for theory and research on personal epistemology. In B. K. Hofer \& P. R. Pintrich ed, Personal epistemology: The psychology of beliefs about knowledge and knowing. New Jersey, USA: Lawrence Erlbaum Associates, Inc.

Pluta, W. J., Chinn, C. A., \& Duncan, R. G. (2011). Learners' epistemic criteria for good scientific models. Journal Research in Science Teaching, 48, 486-511.

Pratiwi, Y. N., Rahayu, S., \& Fajaroh, F. (2016). Socioscientific issues (SSI) in reaction rates topic and its effect on the critical thinking skills of high school students. Jurnal Pendidikan IPA Indonsia, 5, 164-170.

Quìlez, J. A. (2004). Historical approach to the development of chemical equilibrium through the evolution of the affinity concept: some educational suggestions. Chemical Education Research \& Practice, 5, 69-87.

Rahayu, S. (2017). Promoting The 21 $1^{\text {st }}$ Century Scientific Literacy Skills through Innovative Chemistry Instruction. AIP Conference Proceedings, Yogyakarta, Indonesia.

Rahayu, S. (2018). Socio-Scientific Issues (SSI) in Chemistry Education: Enhancing Both Students' \& Transferable Skills. The 2nd Annual International Conference on Mathematics and Science Education, East Java, Indonesia.

Ratcliffe, M., \& Grace, M. (2003). Science education for citizenship. Mcgraw Hill Education, Maidenhead, Berkshire, UK: Open University Press.

Roberts, D. A., \& Bybee, R. W. (2014). Scientific literacy, science literacy, and science education. In N. G.Lederman \& S. K. Abell ed. New York, USA: Routledge.

Sadler, T. D. (2004). Moral and ethical dimensions of socioscientific decision-making as integral components of scientific literacy. Science Education, 13, 9-48.

Sadler, T. D., \& Zeidler, D. L. (2005). Patterns of informal reasoning in the context of socioscientific decision-making. Journal Research and Science Teaching, 42, 112-138.

Sadler, T. D., \& Donelly, L. A. (2006). Socioscientific argumentation: the effects of content knowledge and morality. International Journal Science Education, 28, 1463 1488 .

Sadler, T. D., Barab, S.A., \& Scott, B. M. (2007). What do students gain by engaging in socioscientific inquiry? Research in Science Education, 37(4), 371-391.

Sadler, T.D. (2011). Situating socioscientific issues in classrooms as a means of achieving goals of science education. In Socio-Scientific Issues in the Classroom: Teaching, Learning and Research, Sadler, T.D ed. Netherlands: Springer.

Sadler, T. D., Klosterman, M. L., \& Topcu, M. S. (2011). Learning science content and socio-scientific reasoning through classroom explorations of global climate change. In Socio-scientific issues in the classroom: Teaching, learning and research, Sadler, T. D ed. Netherlands: Springer. 
Sandoval, W.A., Bell, P., Coleman, E., Enyedy, N., \& Suthers, D. (2000). Designing Knowledge Representations for Learning Epistemic Practices of Science. Symposium at the annual meeting of the American Educational Research Association, New Orleans, USA.

Sandoval, W. A., Greene, J. A., \& Bråten, I. (2016). Understanding and promoting thinking about knowledge origins, issues, and future directions of research on epistemic cognition. Review of Research in Education, 40, 457-496.

Saunders, K., \& Rennie, L.J. (2013). A pedagogical model for ethical inquiry into socioscientific issues in science. Research in Science Education, 43(1), 253-274.

Shwartz, Y., Ben-Zvi, R., \& Hofstein, A. (2006). The use of scientific literacy taxonomy for assessing the development of chemical literacy among high-school students. Chemistry Education Research and Practice, 7(4), 203-225.

Sjøberg, S. (2018). The power and paradoxes of PISA: Should inquiry-based science education be sacrificed to climb on the rankings? Nordic Studies in Science Education, 14, 186-202.

Sjöström, J.; Eilks, I. (2018). Reconsidering different visions on scientific literacy and science education based on the concept of bildung. In Cognition, Metacognition, and Culture in STEM Education, Dori, Y.J.; Mevarech, Z.R.; Baker, D.R ed. New York: Springer.

Stevens, R. (2012). Identifying 21 st century capabilities. International Journal of Learning and Change, 6, 123-137.

Stuckey, M., Hofstein, A., Mamlok-Naaman, R., \& Eilks, I. (2013). The meaning of 'relevance' in science education and its implications for the science curriculum. Studies in Science Education, 49(1), 1-34.

Sutiani, A., Situmorang, M., \& Silalahi, A. (2021). Implementation of an inquiry learning model with science literacy to improve student critical thinking skills. International Journal of Instruction, 14(2), 117-138.

Traianou, A. (2006). Teachers' adequacy of subject knowledge in primary science: assessing constructivist approaches from a socio-cultural perspective. International Journal of Science Education, 28, 827-842.

Tsai, C-Y., \& Jack, B. M. (2019). Antecedents Factors influencing ethics-related social and socio-scientific learning enjoyment. International Journal Science Education, 11391158 .

Tyson, L., Treagust, D. F., \& Bucat, R. B. (1999). The complexity of teaching and learning chemical equilibrium. Journal Chemical Education \& Practice, 76, 554-558.

Venville, G. J., \& Dawson, V. M. (2010). The impact of a classroom intervention on grade 10 students' argumentation skills, informal reasoning, and conceptual understanding of science. Journal Research in Science Teaching, 47, 952-977. 
Vieira, R. M., \& Vieira, C. T. (2014). Fostering Scientific Literacy and Critical Thinking in Elementary Science Education. International Journal Science and Mathematics Education, 14, 659-680.

Walker, K.A., \& Zeidler, D. L (2007). Promoting discourse about socioscientific issues through scaffolded inquiry. International Journal of Science Education, 29(11), 13871410 .

Yalvac, B., Tekkaya, C., Cakiroglu, J., \& Kahyaoglu, E. (2007). Turkish pre-service science teachers' views on science technology-society issues. International Journal of Science Education, 29, 331-348.

Yilmaz, I., \& Yalçin, N. (2012). The relationship of procedural and declarative knowledge of science teacher candidates in Newton's Laws of motion to understanding. American International Journal of Contemporary Research, 2, 50-56.

Yörük, N. (2010). The effect of science, technology, society, environment (STSE) interactions on teaching chemistry. Natural Science, 2, 1417-1424.

Zeidler, D.L. (2003). The role of moral reasoning on socioscientific issues and discourse in science education. Dordrecht, Netherlands: Kluwer Academic Press.

Zeidler, D. L., \& Keefer, M. (2003). The role of moral reasoning and the status of socioscientific issues in science education: Philosophical, psychologicla and pedagogical considerations. In The role of moral reasoning and discourse on socioscientific issues in science education, D. L. Zeidler ed. Dordrecht, Netherlands: Kluwer Academic Press.

Zeidler, D.L., Sadler, T.D., Simmons, M.L., \& Howes, E. V. (2005). Beyond STS: A researche-based framework for socioscientific issues education. Science Education, 89(3), 357-377.

Zeidler, D. L., Sadler, T. D., Applebaum, S., \& Callahan, B. E. (2009). Advancing reflective judgment through socio-scientific issues. Journal Research in Science Teaching, 46, 74-101.

Zeidler, D. L., \& Kahn, S. (2014). It's debatable: Using Socioscientific issues to develop scientific literacy, $K-12$. Arlington, Texas, USA: National Science Teachers Association Press

Zeidler, D.L. (2015). Socioscientific issues. In Encyclopedia of Science Education, Gunstone, R ed. Dordrecht, Netherlands: Kluwer Academic Press.

\section{APPENDIX}

Examples of questions about content knowledge, procedural knowledge, and epistemic knowledge

\begin{tabular}{ll}
\hline $\begin{array}{l}\text { Knowledge } \\
\text { Aspect }\end{array}$ & Examples of questions \\
\hline Content & $\begin{array}{l}\text { Based on the context of "Ozone and CFCs", answer the questions according to your understanding. } \\
\text { Ozone and CFCs } \\
\text { The atmosphere is a layer of gases that covers the entire surface of the Earth. The atmosphere functions as a } \\
\text { protector of the Earth while maintaining the temperature and humidity on Earth. However, the atmosphere and } \\
\text { the gas components in the atmosphere are disrupted due to human activities on Earth, including the discharge } \\
\text { of factory waste gases into the air and the use of various CFC products. In the atmosphere, there is an ozone }\end{array}$ \\
&
\end{tabular}


layer that protects living things from the dangers of ultraviolet radiation.

One of the causes of the depletion of the ozone layer in the atmosphere is CFC compounds. CFC compounds are not formed in nature but are synthesized by humans used for various human purposes. Due to the nature of $\mathrm{CFCs}$ that are non-toxic, non-flammable, inexpensive, and widely available, experts then created air conditioning (Air Conditioning) which is currently commonly used in homes, offices, schools, and others. Ironically, the ideal properties of CFCs are harmful to the Earth's atmosphere. CFC molecules and their derivatives, such as $\mathrm{CCl}_{2} \mathrm{~F}_{2}$, can survive in the atmosphere for 120 years. Sunlight can break the bonds in $\mathrm{CFCs}$ to form very reactive $\mathrm{Cl}$ atomic radicals that react with ozone which reduces the ozone concentration in the atmosphere. The radical atomic $\mathrm{Cl}$ turned out to be the catalyst for the ozone decomposition reaction after being investigated, whose energy diagram is as follows:

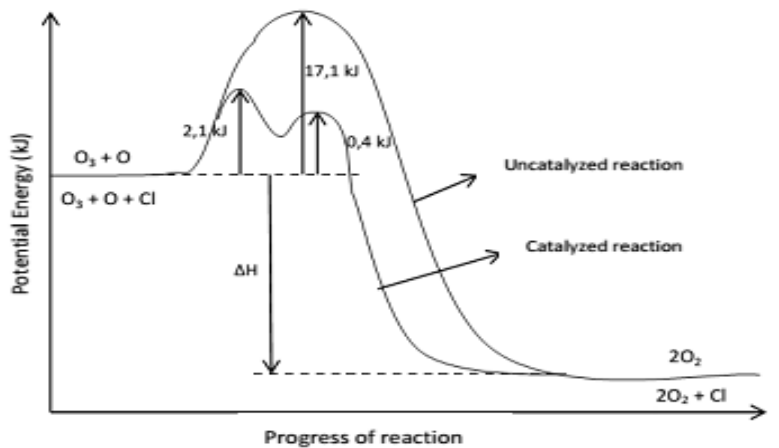

Questions:

a. Consider the energy diagram of the breakdown of ozone into oxygen in the presence of a $\mathrm{Cl}$ atomic catalyst (from $\mathrm{CFC}$ ). According to the diagram, what is the role of the $\mathrm{Cl}$ catalyst in the breakdown of ozone?

b. Which of the following statements is correct about the energy diagram above!

[1] The reaction rate without a catalyst is lower than in the presence of a catalyst

[2] The reaction with the catalyst decreases the activation energy of the decomposition of ozone

[3] The reaction with a catalyst does not affect the $\Delta \mathrm{H}$ value of ozone decomposition

[4] The $\mathrm{Cl}$ catalyst also reacts but is recovered after the reaction

c. Explain how the characteristics of the catalyst in the ozone decomposition reaction above?

Epistemic The diagram in the context of 'Ozone and CFCs' interprets experimental data conducted by scientists. Are the findings of scientific knowledge or scientific information always based on experiments? Explain why!

Procedural It is known that the tools and materials and the stages of the work procedure from the experiment determine the factors that affect the reaction rate is as follows.

* Tools and materials: dropper pipettes, $50 \mathrm{~mL}$ beaker ( 3 pieces), $50 \mathrm{~mL}$ measuring cup, white paper marked with a red $\mathrm{X}$, stopwatch, $1 \mathrm{M} \mathrm{HCl}$ solution, $1 \mathrm{M} \mathrm{Na}_{2} \mathrm{~S}_{2} \mathrm{O}_{3}$ solution, $0.5 \mathrm{M}$, and $0,1 \mathrm{M}$.

* Work procedures:

a) In glass 1, put in $20 \mathrm{~mL}$ of $1 \mathrm{M} \mathrm{Na}_{2} \mathrm{~S}_{2} \mathrm{O}_{3}$ solution, glass 2 put in $20 \mathrm{~mL}$ of $0.5 \mathrm{M} \mathrm{Na}_{2} \mathrm{~S}_{2} \mathrm{O}_{3}$ solution, and glass 3 put in $20 \mathrm{~mL}$ of $1 \mathrm{M} \mathrm{Na}_{2} \mathrm{~S}_{2} \mathrm{O}_{3}$ solution.

b) Add $5 \mathrm{ml}$ of $1 \mathrm{M} \mathrm{HCl}$ solution into glass 1, then with a stopwatch, record the time counted from the addition of the $\mathrm{HCl}$ solution until the $\mathrm{X}$ mark on the paper was no longer visible.

c) Label 3 pieces of $50 \mathrm{~mL}$ beaker with 1,2 and 3

d) Place the labeled beaker on an X-marked paper

e) Repeat the same steps for glasses 2 and 3

Question:

a. Are the steps or stages in the work procedure above correct? If it's wrong, set the correct working steps for the experiment above!

b. From this work procedure, what will be tested, and what is the purpose?

c. If we want to see the effect of temperature on the reaction rate, what work steps should be added to the work procedure above?

d. If we add a work step as follows: Prepare $5 \mathrm{~mL}$ of $1 \mathrm{M} \mathrm{Na}_{2} \mathrm{~S}_{2} \mathrm{O}_{3}$ solution, put it in a beaker and add 10 $\mathrm{mL}$ of aqua dest and repeat the steps in point $\mathrm{b}$. Then repeat this step with the addition of $20 \mathrm{~mL}$ and 30 $\mathrm{mL}$ of distilled water. Describe what could be tested and resulted from this step?

International Journal of Instruction, January $2022 \bullet$ Vol.15, No.1 